\title{
Neuronal cytoplasmic inclusions in tau, TDP-43, and FUS molecular subtypes of frontotemporal lobar degeneration share similar spatial patterns
}

\author{
Richard A. Armstrong \\ Vision Sciences, Aston University, Birmingham, United Kingdom
}

\begin{abstract}
The 'prion-like' transfer of pathogenic proteins may play a role in the pathogenesis of frontotemporal lobar degeneration (FTLD). Propagation of such proteins along anatomical pathways may give rise to specific spatial patterns of the 'signature' neuronal cytoplasmic inclusions (NCI) characteristic of these disorders. Hence, the spatial patterns of the NCI were compared in three molecular subtypes of FTLD: (1) two variants of FTLD-tau, viz. corticobasal degeneration (CBD) and Pick's disease (PID), (2) FTLD with transactive response (TAR) DNA-binding protein 43 (TDP-43)-immunoreactive inclusions (FTLD-TDP), and (3) FTLD with 'fused in sarcoma' (FUS)-immunoreactive inclusions (FTLD-FUS). Regardless of molecular pathology, the NCl in the frontal and temporal cortex were most frequently aggregated into clusters, the clusters being regularly distributed parallel to the pia mater. In a significant proportion of regions, the regularly distributed clusters were in the size range 400-800 $\mu \mathrm{m}$, approximating the dimension of cell columns associated with the cortico-cortical pathways. Clusters of NCI were significantly larger in FTLD-tau compared with FTLD-TDP and FTLD-FUS. The data suggest that cortical NCI in different molecular subtypes of FTLD all share a similar spatial pattern in the frontal and temporal cortex consistent with a 'prion-like' spread of pathological proteins along anatomical pathways. However, a more selective group of neurons appears to be affected in FTLD-TDP and FTLD-FUS than in FTLD-tau.
\end{abstract}

Key words: frontotemporal lobar degeneration (FTLD), spatial patterns, neuronal cytoplasmic inclusions (NCI), 'prion-like' spread.

\section{Introduction}

Most cases of frontotemporal lobar degeneration (FTLD) can be classified into three molecular subtypes: (1) FTLD with tau-immunoreactive inclusions (FTLDtau), a heterogeneous group of disorders, examples of which include corticobasal degeneration (CBD), Pick's disease (PiD), and progressive supranuclear palsy (PSP), (2) FTLD with transactive response (TAR) DNA-binding protein 43 (TDP-43)-immunoreactive inclusions (FTLD-TDP), and (3) FTLD with 'fused in sarcoma' (FUS)-immunoreactive inclusions (FTLD-FUS) [42]. In all of these disorders, abnormally aggregated proteins result in the formation of phosphorylated 'signature' neuronal cytoplasmic inclusions (NCI), FUS 
protein in FTLD-FUS being additionally hypomethylated [48], most abundantly in the frontal and temporal cortex [15,29,52].

Many pathogenic proteins can exhibit 'prion-like' behaviour, i.e., they act as propagating entities or 'seeds' amplifying their pathogenic conformation similar to prion protein (PrPsc) in prion diseases $[35,37]$. As a consequence, proteins may spread along anatomical pathways and the clinical phenotype of the disease could depend, in part, on variations in this spread and the specific pathways affected. If pathogenic proteins spread along anatomical connections, then the resulting $\mathrm{NCl}$ may exhibit a spatial distribution pattern in the cortex which reflects this spread [10]. In Creutzfeldt-Jakob disease (CJD), in which propagation of $\mathrm{PrPs}^{\mathrm{sc}}$ along anatomical pathways is well documented [19-21], PrPsc deposits are clustered in the cerebral cortex, the clusters being regularly distributed parallel to the pia mater $[11,13]$. This pattern of clustering may therefore be a marker for the spread of PrPsc $[12,14]$ and other proteins among brain regions along anatomical pathways [10]. In addition, tau and TDP-43 but not FUS may share amyloid properties [23] and therefore inclusions in FTLD-FUS may have a different spatial pattern than in the other subtypes. Hence, the present study compared the spatial patterns of $\mathrm{NCl}$ in cases representing the three subtypes of FTLD: (1) two variants of FTLD-tau, viz. CBD and PiD, (2) FTLD-TDP, and (3) FTLD-FUS. Two main questions were addressed: (1) Are the spatial patterns of the $\mathrm{NCl}$ in the three disorders consistent with the propagation of pathological proteins? (2) Did molecular pathology influence the spatial patterns of the $\mathrm{NCl}$ ?

\section{Material and methods \\ Cases}

Demographic data and diagnostic criteria for the three molecular subtypes of FTLD are shown in Table I. CBD $(n=12)$ and PiD $(n=10)$ cases (FTLD-tau) were obtained from the Brain Bank, Department of Neuropathology, Institute of Psychiatry, King's College, London, UK. FTLD-TDP cases $(n=32)$ were obtained from Washington University, St Louis, MO., USA). Of the 32 FTLD-TDP cases, 20 were familial (at least one first degree relatives affected) and of these, 10 cases had GRN mutations [18,22,28,41,43], one had a VCP gene mutation, and one case was associated with the C90RF72 gene $[40,46]$. The majority $(n=7)$ of the GRN cases were from a single hereditary dysphasic disinhibition dementia (HDDD) family (HDDD2) [43] and the remainder $(n=3)$ from a HDDD1 family [22]. No genetic defects have been identified to date in the remaining eight familial cases but none of these had a strong autosomal dominant pattern of inheritance. FTLD-FUS cases $(n=10)$ [16] were obtained from centres in Canada, Norway, Spain, Japan (one case from each), and from France, the UK, and the USA (two cases from each) [25].

\section{Tissue preparation}

After death, the consent of the next of kin was obtained for brain removal following local Ethical Committee procedures and the 1999 Declaration of Helsinki (as modified Edinburgh, 2000). Brain tissue was preserved in buffered $10 \%$ formalin or $4 \%$ paraformaldehyde. Tissue blocks were taken from frontal and temporal lobe, fixed in 10\% phosphate buffered formal-saline, and embedded in paraffin wax. Immunohistochemistry (IHC) was performed on 6-8 $\mu \mathrm{m}$ sections using appropriate antibodies (Table I). Sections were counterstained with haematoxylin.

\section{Morphometric methods}

In the superior frontal gyrus (SFG), inferior temporal gyrus (ITG), and parahippocampal gyrus (PHG), $\mathrm{NCl}$ were counted along a strip of tissue (3200 to $6400 \mu \mathrm{m}$ in length) located parallel to the pia mater, using $250 \times 50 \mu \mathrm{m}$ sample fields arranged contiguously [4]. The sample fields were located both in the upper (approximating to layers II/III) and lower (approximating to layers V/VI) cortex, the short edge of the sample field being orientated parallel with the pia mater and aligned with guidelines marked on the slide. The number of $\mathrm{NCl}$ present in each sample field was counted.

\section{Data analysis}

The data were analysed by spatial pattern analysis $[2,4,6,7,9]$. This method uses the variance-mean ratio $(\mathrm{V} / \mathrm{M})$ to determine whether the $\mathrm{NCl}$ were distributed randomly $(V / M=1)$, regularly $(V / M<1)$, or were clustered $(V / M>1)$ along a strip of tissue. Counts of $\mathrm{NCl}$ in adjacent sample fields were added together successively to provide data for increasing field sizes, e.g., $50 \times 250 \mu \mathrm{m}, 100 \times 250 \mu \mathrm{m}, 200 \times$ $250 \mu \mathrm{m}$, etc., up to a size limited by the length of the strip sampled. V/M was plotted against field 
Table I. Summary of demographic details, diagnostic criteria, and immunohistochemistry (IHC) of the frontotemporal lobar degeneration (FTLD) subtypes

\begin{tabular}{|lccccc|}
\hline Disorder & $n$ & Age mean (SD) & M : F & IHC & Diagnostic criteria \\
\hline FTLD-tau (CBD) & 12 & $64.07(9.07)$ & $8: 4$ & TP007 (tau) & NIH-ORD \\
\hline FTLD-tau (PiD) & 10 & $65.03(11.3)$ & $7: 3$ & TP70 (tau) & Cairns et al. [26] \\
\hline FTLD-TDP & 32 & $71.03(1.62)$ & $16: 16$ & pTDP-43 & Cairns et al. [26] \\
\hline FTLD-FUS & 10 & $45.3(12.1)$ & $7: 3$ & FUS & Cairns et al. [26] \\
\hline
\end{tabular}

CBD - corticobasal degeneration, FUS - 'fused in sarcoma', PiD - Pick's disease, TDP-43 - transactive response (TAR) DNA-binding protein 43, $n$ - number of cases studied, $M$ - male, $F$-female.

Diagnostic criteria: National Institutes of Health-Office of Rare Diseases (NIH-ORD); diagnostic criteria for FTLD-TDP and FTLD-FUS according to Cairns et al. (2007)

size to determine whether the clusters of $\mathrm{NCl}$ were regularly or randomly distributed and to estimate the mean cluster size parallel to the tissue boundary. A V/M peak indicates the presence of regularly spaced clusters. The statistical significance of a peak was tested using the ' $t$ ' distribution [4]. The effect of molecular pathology on the frequency of the different types of spatial pattern was tested using chisquare $\left(\mathrm{X}^{2}\right)$ contingency tables. In addition, mean cluster sizes of $\mathrm{NCl}$ were compared between FTLD subtypes using a one-way analysis of variance (ANOVA) (STATISTICA software, StatSoft Inc., 2300 East $14^{\text {th }}$ St, Tulsa, Ok, 74104, USA) followed by Tukey's HSD post-hoc test.

\section{Results}

Examples of the $\mathrm{NCl}$ in the three FTLD subtypes are shown in Figures 1 and 2. Consistent morphological differences were apparent among disorders, spherical inclusions being predominant in $\mathrm{PiD}$ and FTLD-FUS, while NCI in CBD and FTLD-TDP were more variable, being spherical, spicular, or flame-shaped.

Examples of the spatial patterns of the $\mathrm{NCl}$ observed in a single brain region (ITG, layers II/III) in the three FTLD subtypes are shown in Figure 3. The $\mathrm{V} / \mathrm{M}$ ratios of the $\mathrm{NCl}$ in CBD (FTLD-tau) increased with field size without reaching a peak, suggesting a large cluster of $\mathrm{NCl}$ at least $1600 \mathrm{~mm}$ in diameter. The $\mathrm{V} / \mathrm{M}$ ratios of the $\mathrm{NCl}$ in FTLD-TDP and FTLD-FUS, however, reached peaks at field sizes of $200 \mathrm{~mm}$ and $100 \mathrm{~mm}$ respectively, suggesting clusters of inclusions, $200 \mathrm{~mm}$ and $100 \mathrm{~mm}$ in diameter, which were regularly distributed parallel to the pia mater.

A comparison of the spatial patterns exhibited by the $\mathrm{NCl}$ in FTLD-tau, FTLD-TDP, and FTLD-FUS in all cases and regions is shown in Table II. Most frequently, $\mathrm{NCl}$ were clustered and the clusters were regularly distributed parallel to the pia mater. This spatial pattern varied in frequency among subtypes
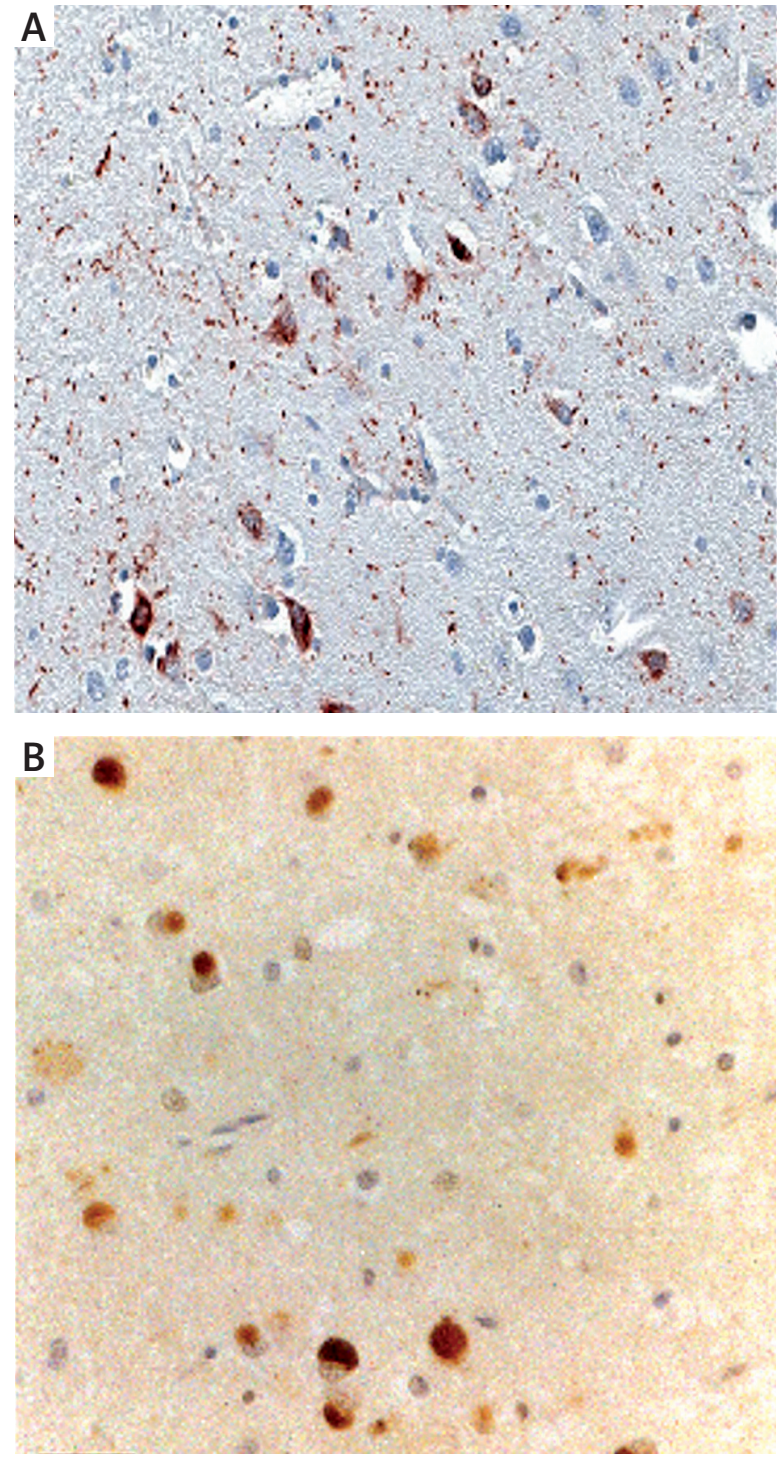

Fig. 1. Neuronal cytoplasmic inclusions ( $\mathrm{NCl})$ in frontotemporal lobar degeneration (FTLD) with tau-immunoreactive inclusions (FTLD-tau): A) corticobasal degeneration (CBD) (antibody TP007, bar $=100 \mu \mathrm{m})$ and B) Pick's disease (PiD) (Antibody tau TP70, bar $=50 \mu \mathrm{m}$ ). 

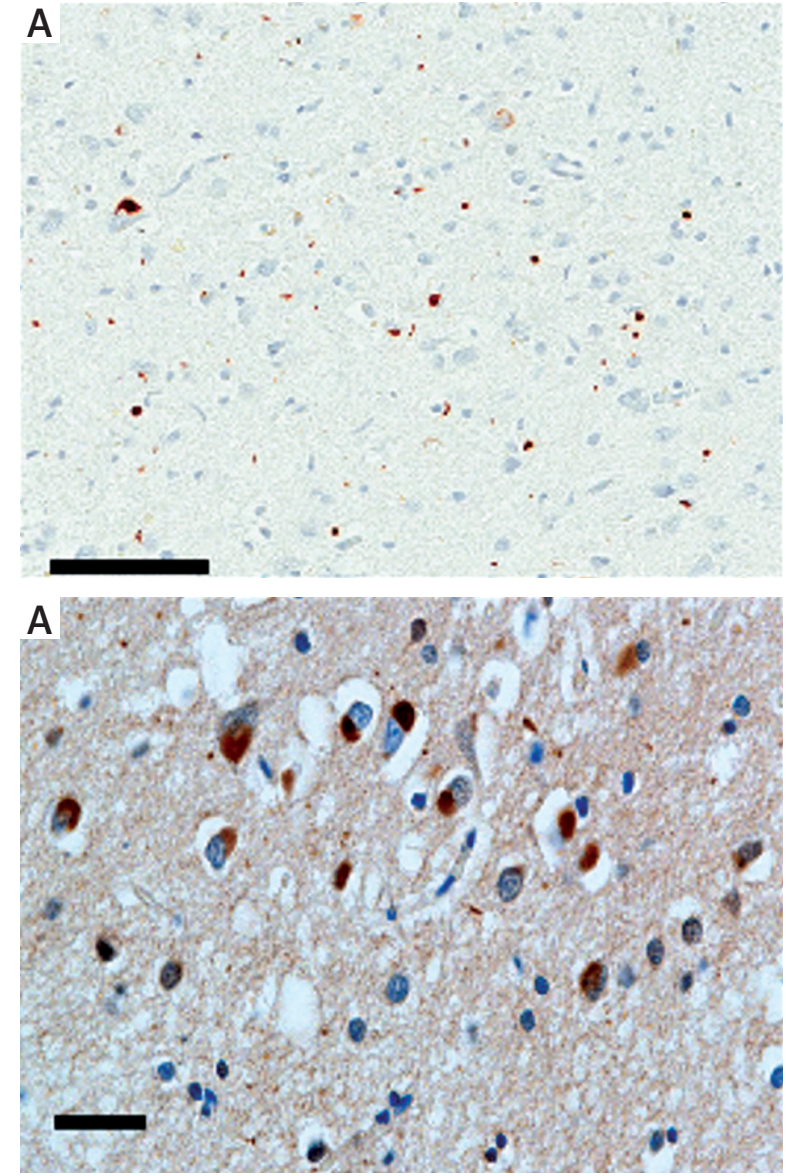

Fig. 2. Neuronal cytoplasmic inclusions (NCI) in frontotemporal lobar degeneration (FTLD): A) with TDP-43-immunoreactive inclusions (FTLDTDP) (antibody pTDP-43, bar $=100 \mu \mathrm{m}$ ) and B) with FUS-immunoreactive inclusions (FTLD-FUS) (antibody FUS, bar $=100 \mu \mathrm{m}$ ).

from $45 \%$ of cortical gyri in FTLD-TDP to $74 \%$ in FTLD-FUS. Larger-scale clustering, in which the $\mathrm{NCI}$ occurred in clusters of at least $1600 \mathrm{~mm}$ in diameter, but without regular spacing, was also present in some regions. Within FTLD-tau, there were no significant differences between the spatial patterns of the $\mathrm{NCl}$ in CBD and PiD $\left(\mathrm{X}^{2}=2.37,3 \mathrm{DF}, p>0.05\right)$ and in FTLD-TDP between familial and sporadic cases $\left(\mathrm{X}^{2}=3.11,6 \mathrm{DF}, p>0.05\right)$. However, there were significant differences in the proportions of the different spatial patterns among FTLD subtypes $\left(\mathrm{X}^{2}=65.12\right.$, 9DF, $\left.p<0.001\right)$, comparisons of the subtypes in pairs suggesting that FTLD-tau exhibited more frequent large-scale clustering than FTLD-TDP $\left(\mathrm{X}^{2}=51.15,3 \mathrm{DF}, p<0.001\right)$ and FTLD-FUS $\left(\mathrm{X}^{2}=21.47\right.$, $3 \mathrm{DF}, p<0.001)$. In addition, the frequency of random

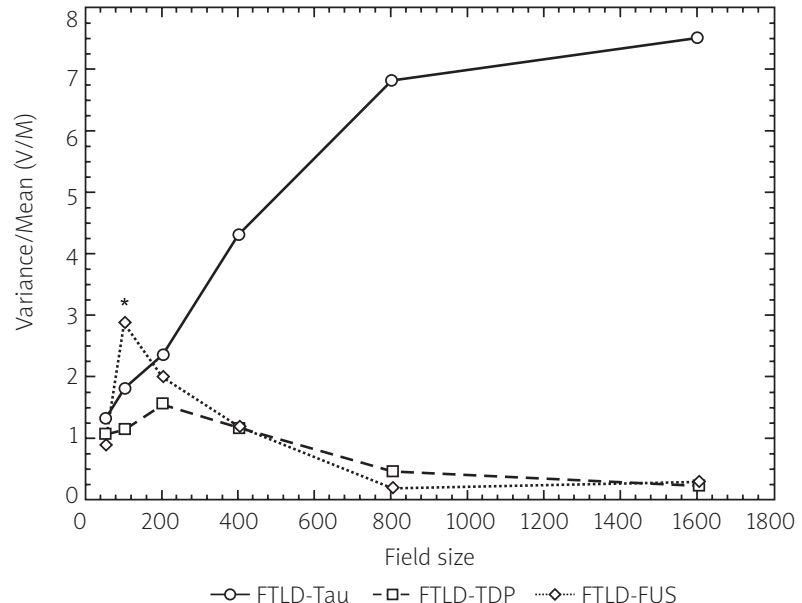

Fig. 3. Pattern analysis plots showing examples of the spatial patterns exhibited by neuronal cytoplasmic inclusions $(\mathrm{NCl})$ in the inferior temporal gyrus (ITG): A comparison of three subtypes of frontotemporal lobar degeneration (FTLD), viz. FTLD-tau (CBD), FTLD-TDP, and FTLD-FUS ( ${ }^{*}$ indicates significant variance/mean peaks).

distributions was higher in FTLD-TDP. In all subtypes, a small number of regions exhibited a more complex spatial pattern in which small, regularly distributed clusters were themselves aggregated into larger 'superclusters'.

A comparison of estimated cluster sizes of the $\mathrm{NCl}$ in the three subtypes is shown in Table III. There was a significant difference in mean cluster size among subtypes ( $F=28.68, p<0.001)$, post-hoc tests suggesting that cluster sizes were significantly larger in FTLD-tau than in FTLD-TDP and FTLD-FUS. In addition, the proportion of cortical regions in which regularly distributed clusters were within the size range 400-800 $\mathrm{mm}$ varied among subtypes $\left(\mathrm{X}^{2}=7.94,2 \mathrm{DF}\right.$, $p<0.05)$, FTLD-tau variants exhibiting a greater proportion of regions within this size range $\left(\mathrm{X}^{2}=5.43\right.$, 1DF, $p<0.05)$ compared with FTLD-TDP and FTLDFUS, which exhibited a similar range $\left(\mathrm{X}^{2}=1.42,1 \mathrm{DF}\right.$, $p>0.05)$.

\section{Discussion}

The data suggest that in all three molecular subtypes of FTLD, the $\mathrm{NCl}$ were clustered in the frontal and temporal cortex and, in a significant proportion of gyri, the clusters were regularly distributed parallel to the pia mater [13]. The frequency of this spatial pattern varied among subtypes, being most frequent in FTLD-FUS (74\%) and least frequent in FTLD-TDP 
Table II. Frequency of the different types of spatial pattern ( $\mathrm{R}$ - random, RG - regular) exhibited by neuronal cytoplasmic inclusions ( $\mathrm{NCl}$ ) in three subtypes of frontotemporal lobar degeneration (FTLD): FTLD-tau, viz. Pick's disease (PiD), and corticobasal degeneration (CBD), FTLD-TDP, and FTLD-FUS. Data in parentheses indicate the number of gyri in which regular clusters of inclusions were in the size range 400-800 $\mu \mathrm{m}$

\begin{tabular}{|llcccc|}
\hline Disorder & Subtype & $\mathrm{R}$ & $\mathrm{RG}$ & Regular clusters $(50-1600 \mu \mathrm{m})$ & Large clusters $(\geq 1600 \mu \mathrm{m})$ \\
\hline \multirow{3}{*}{ FTLD-tau } & CBD & 2 & 2 & $48(24)$ & 24 \\
\cline { 2 - 6 } & PiD & 1 & 0 & $27(17)$ & 20 \\
\hline \multirow{3}{*}{ FTLD-TDP } & All cases & 36 & 17 & $60(28)$ & 19 \\
\cline { 2 - 6 } & GRN mutation & 16 & 5 & $23(11)$ & 5 \\
\cline { 2 - 6 } & Non-GRN familial cases & 9 & 4 & $16(7)$ & 7 \\
\cline { 2 - 6 } & Sporadic cases & 11 & 8 & $21(10)$ & 4 \\
\hline \multirow{2}{*}{ FTLD-FUS } & - & 7 & 3 & $39(11)$ & 7 \\
\hline
\end{tabular}

Chi-square $\left(\chi^{2}\right)$ contingency tests:

Between subtypes of FTLD-tau: $\chi^{2}=2.37(3 D F, p>0.05)$

Between subtypes of FTLD-TDP: $\chi^{2}=3.11(6 D F, p>0.05)$

All groups: $\chi^{2}=65.12(9 D F, p<0.001)$

Comparing FTLD-tau and FTLD-TDP: $\chi^{2}=51.15(3 D F, p<0.001)$

Comparing FTLD-tau and FTLD-FUS: $\chi^{2}=21.47(3 D F, p<0.001)$

Comparing FTLD-TDP and FTLD-FUS: $\chi^{2}=12.05(3 D F, p<0.01)$

Table III. Estimated mean cluster sizes (SE - standard error) of the neuronal cytoplasmic inclusions (NCI) in the cortex of three subtypes of frontotemporal lobar degeneration (FTLD), viz. FTLD-tau, FTLD-TDP, and FTLD-FUS

\begin{tabular}{|lcccc|}
\hline Subtype & Mean cluster size $(\mu \mathrm{m})$ & Range $(\mu \mathrm{m})$ & SE & Percentage of gyri in range 400-800 $(\mu \mathrm{m})$ \\
\hline FTLD-tau (CBD) & 1990 & $100-1600$ & 243.9 & 32 \\
\hline FTLD-tau (PiD) & 3229 & $200-1600$ & 385.9 & 51 \\
\hline FTLD-TDP & 302 & $50-1600$ & 97.2 & 10 \\
\hline FTLD-FUS & 474 & $50-1600$ & 134.4 & 21 \\
\hline
\end{tabular}

Comparison of cluster sizes (1-way ANOVA with 'Tukey HSD' post-hoc test): Between disorders F = $23.52(p<0.001)$, post-hoc FTLD-tau > FTLD-TDP = FTLD-FUS Comparison of proportions of regions with cluster sizes in the range $400-800 \mathrm{~mm}$ :

All groups $\chi^{2}=7.94(2 D F, p<0.05)$

Comparing FTLD-tau and. FTLD-TDP + FTLD-FUS $\chi^{2}=5.43(1 D F, p>0.05)$

Comparing FTLD-TDP and FTLD-FUS $\chi^{2}=1.42(1 D F, p>0.05)$

(45\%). Similar spatial patterns have been observed in Alzheimer's disease (AD) [3,8], in various synucleinopathies such as Parkinson's disease dementia (PDD) [10] and in CJD [11,13]. Hence, although FUS may not share the amyloid-like properties of tau and TDP-43 [23], the similar spatial patterns exhibited suggest that similar pathological processes may be present in diseases characterised by different molecular pathologies [34].

The regular distribution of clusters of $\mathrm{NCl}$ is consistent with their development in association with the cells of origin of specific cortical pathways $[3,14]$. In cortical regions, these cells are clustered and occur in bands which are regularly distributed along the cortex. Individual bands of cells traverse the cortical layers and, in the primate brain, vary in width from 400-500 mm up to 800-1000 $\mu \mathrm{m}$ depending on the region $[30,36]$. In a proportion of gyri, the width of the $\mathrm{NCl}$ clusters and their distribution along the cortex suggest an association with these pathways with two exceptions. First, in some gyri, $\mathrm{NCl}$ occurred in larger clusters greater than 800-1600 mm, especially in FTLD-tau, and in some regions, small clusters of $\mathrm{NCl}$ were aggregated into larger 'superclusters'. These results suggest that the smaller, regularly distributed clusters of inclusions could 'coalesce' to form larger clusters as the disease develops [3]. Second, $\mathrm{NCl}$ were randomly distributed in some gyri, especially in FTLD-TDP, which may be the result of the low density of pTDP-43-immunoreactive inclusions observed in some cases [15].

Differences in cluster sizes of $\mathrm{NCl}$ among subtypes suggest variation in the degree to which specific cortical columns may be affected by the different molecular pathologies. Hence, significantly larger clusters of $\mathrm{NCl}$ were observed in FTLD-tau than in FTLD- 
TDP and FTLD-FUS, and in the latter two disorders the clusters were usually smaller than the estimated diameter of the cell columns of the cortico-cortical projections. Hence, a more localised pattern of cortical degeneration appears to be present in FTLDTDP and FTLD-FUS. Compared with tau, which is widespread in neurons and important in the assembly and stabilisation of microtubules [27,51], both TDP-43 and FUS have more specific roles, TDP-43 in mRNA function, DNA repair, and in non-coding RNA metabolism [45] while FUS is important in regulating gene expression including transcription, splicing, and RNA transport [31]. In both TDP-43 and FUS, nuclear clearance results in the immediate aggregation in the cytoplasm of cells [33]. In addition, TDP-43 can also repress non-conserved cryptic axons, many of which are cell type specific, and therefore loss of TDP-43 function could result in the degeneration of specific groups of cells [38,39].

Of particular interest is whether the observed spatial patterns could reflect the 'prion-like' behaviour of pathogenic proteins [32,35,37,47]. Several observations are consistent with this hypothesis. First, tau may exit host cells, transfer between cells, gain access to new cells, and create pathology within these cells [47]. Second, by analogy with the scrapie form of prion protein $\left(\mathrm{PrP}^{\mathrm{sc}}\right)$, nucleation or seeding activity of tau may result in a core of an $\mathrm{NCl}$ of transferred tau surrounded by additional layers of cytoplasmic tau contributed by the host cell. Third, the spatial patterns of $\mathrm{NCl}$ in all three subtypes exhibited a similar spatial pattern to PrPsc deposits in CJD [11,13]. Fourth, TDP-43 is a dimeric nuclear protein in which the $\mathrm{C}$-terminal region exhibits 'prion-like' behaviour [49], the majority of gene mutations associated with frontotemporal dementia (FTD) and motor neuron disease (MND) being located in this region [49]. Moreover, tandem repeats of the 'prion-like' $\mathrm{Q} / \mathrm{N}$ region of TDP-43, when fused to additional TDP-43, can cause aggregate formation in neuronal and non-neuronal cell lines [24]. Fifth, aggregates of phosphorylated TDP-43 (pTDP-43) are frequently present in axons of hypoglossal and facial nerves and in spinal cord anterior cells in MND, consistent with propagation of the protein [44], while FUS activity is found in granules in gray matter of the brain stem and spinal cord, which co-localise with synaptophysin [1], consistent with transport of the protein and synaptic disconnection. Sixth, stress granules are foci of cytoplasmic RNA formed in response to stress and, among many other proteins, also exhibit TDP-43 and FUS immunoreactivity [17]. Hence, the domains involved in the phase separation of liquid droplets such as stress granules may be a precursor to aggregation and propagation of proteins. Hence, cell-to-cell transfer of pathological proteins along anatomical pathways may be a common mechanism determining cortical degeneration in a variety of FTLD molecular subtypes.

In conclusion, FTLD characterised by $\mathrm{NCl}$ expressing different molecular pathologies exhibit similar spatial patterns in the cerebral cortex, consistent with an association with specific anatomical pathways. The data provide some support for the hypothesis that a 'prion-like' cell-to-cell transfer of pathogenic proteins occurs across different subtypes of FTLD. Different FTLD subtypes therefore may be amenable to similar interventions; e.g., immunotherapy which targets extracellular pathogenic proteins could lead to their removal, thus preventing or slowing cell-to-cell propagation [50].

\section{Acknowledgments}

I would like to thank the families of patients, whose generosity made this research possible. In addition, the following are thanked for making tissue sections available for this study: Knight Alzheimer's Disease Research Center, Washington University School of Medicine, St. Louis, MO, USA, Brain Bank, Institute of Psychiatry, King's College London, London, UK, William Ellis (Department of Pathology, University of California, Davis, Sacramento, CA, USA), Ronald L. Hamilton (Department of Pathology, University of Pittsburgh, Pittsburgh, PA, USA), Ian R. A. Mackenzie (Department of Pathology, Vancouver General Hospital, Vancouver, Canada), E. Tessa Hedley-Whyte (Massachusetts General Hospital and Harvard Brain Tissue Resource Center, Belmont, MA, USA), Marla Gearing (Center for Neurodegenerative Disease, Emory University, Atlanta, GA, USA), Robert Perry Department of Neuropathology, Newcastle General Hospital, Newcastle-upon-Tyne, NE4 6BE, UK), Charles Duyckaerts, Laboratoire de Neuropathologie, Hôpital de la Salpêtrière, AP-HP, 75651, Paris, France), Felix Cruz-Sanchez (Institute of Neurological and Gerontological Sciences, International University of Catalonia, Barcelona, Spain), Kari Skullerud (Department of Pathology, Rikshospitalet, N-0027, Oslo, Norway), Eileen Bigio (Depart- 
ment of Pathology, Northwestern University Medical School, Chicago, Illinois, USA), and Hideaki Yokoo (Department of Pathology, Gunma University School of Medicine, Maebashi, Japan).

\section{Disclosure}

\section{Author reports no conflict of interest.}

\section{References}

1. Aoki N, Higashi S, Kawakami I, Kobayashi Z, Hosokawa M, Katsuse O, Togo T, Hirayssu Y, Akiyama H. Localization of fused in sarcoma (FUS) protein to the post-synaptic density in the brain. Acta Neuropathol 2012; 124: 383-394.

2. Armstrong RA. The usefulness of spatial pattern analysis in understanding the pathogenesis of neurodegenerative disorders, with special reference to plaque formation in Alzheimer's disease. Neurodegeneration 1993; 2: 73-80.

3. Armstrong RA. Is the clustering of neurofibrillary tangles in Alzheimer's patients related to the cells of origin of specific cortico-cortical projections? Neurosci Lett 1993; 160: 57-60.

4. Armstrong RA. Analysis of spatial patterns in histological sections of brain tissue. J Neurosci Meth 1997; 73: 141-147.

5. Armstrong RA. Quantifying the pathology of neurodegenerative disorders: quantitative measurements, sampling strategies and data analysis. Histopathology 2003; 42: 521-529.

6. Armstrong RA. Methods of studying the planar distribution of objects in histological sections of brain tissue. J Microsc (Oxf) 2006; 221: 153-158.

7. Armstrong RA. Measuring the spatial arrangement patterns of pathological lesions in histological sections of brain tissue. Folia Neuropathol 2007; 44: 229-237.

8. Armstrong RA. Clustering and periodicity of neurofibrillary tangles in the upper and lower cortical laminae in Alzheimer's disease. Folia Neuropathol 2008; 46: 26-31.

9. Armstrong RA. Quantitative methods in neuropathology. Folia Neuropathol 2009; 48: 217-230.

10. Armstrong RA. Evidence from spatial pattern analysis for the anatomical spread of a-synuclein pathology in Parkinson's disease dementia. Folia Neuropathol 2017; 55: 23-30.

11. Armstrong RA, Lantos PL, Cairns NJ. The spatial pattern of prion protein deposits in patients with sporadic Creutzfeldt-Jacob disease. Neuropathology 2001; 21: 19-24.

12. Armstrong RA, Lantos PL, Cairns NJ. What does the study of spatial patterns of pathological lesions tell us about the pathogenesis of neurodegenerative disease? Neuropathology 2001; 21 1-12.

13. Armstrong RA, Cairns NJ, Ironside JW, Lantos PL. The spatial patterns of prion protein deposits in cases of variant Creutzfeldt-Jakob disease. Acta Neuropathol 2002; 104: 665-669.

14. Armstrong RA, Cairns NJ, Lantos PL. Are pathological lesions in neurodegenerative disorders the cause or the effect of the degeneration? Neuropathology 2002; 22: 114-127.

15. Armstrong RA, Ellis W, Hamilton RL, Mackenzie IRA, Hedreen J, Gearing M, Montine T, Vonsattel JP, Head E, Lieberman AP, Cairns NJ. Neuropathological heterogeneity in frontotemporal lobar degeneration with TDP-43 proteinopathy: a quantitative study of 94 cases using principal components analysis. J Neural Transm 2010; 117: 227-239.

16. Armstrong RA, Gearing M, Bigio EH, Cruz-Sanchez FF, Duyckaerts C, Mackenzie IRA, Perry RH, Skullerud K, Yokoo H, Cairns NJ. Spatial patterns of FUS-immunoreactive neuronal cytoplasmic inclusions $(\mathrm{NCl})$ in neuronal intermediate filament inclusion disease. J Neural Transm 2011; 118: 1651-1657.

17. Aulas A, Vande Velde C. Alterations in stress granule dynamics driven by TDP-43 and FUS: a link to pathological inclusions in ALS? Front Cell Neurosci 2015; 9: Article Number 423.

18. Baker M, Mackenzie IR, Pickering-Brown SM, Gass J, Rademakers R, Lindholm C, Snowden J, Adamson J, Sadovnick AD, Rollinson S, Cannon A, Dwosh E, Neary D, Melquist S, Richardson A, Dickson D, Berger Z, Eriksen J, Robinson T, Zehr C, Dickey CA, Crook R, McGowan E, Mann D, Boeve B, Feldman H, Hutton M. Mutations in progranulin cause tau-negative frontotemporal dementia linked to chromosome 17. Nature 2006; 442: 916-919.

19. Beekes M, McBride, PA, Baldauf E. Cerebral targeting indicates vagal spread of infection in hamsters fed with scrapie. J Gen Virol 1998; 79: 601-607.

20. Beekes M, McBride PA. Early accumulation of pathological prion protein in the enteric nervous system and gut-associated lymphoid tissue of hamsters orally infected with scrapie. Neurosci Lett 2000; 278: 181-184.

21. Beekes M, Thomzig A, Schultz-Schaeffer W, Burger R. Is there a risk of prion-like transmission by Alzheimer- or Parkinson-associated protein particles. Acta Neuropathol 2014; 128: 463-476.

22. Behrens MI, Mukherjee O, Tu PH, Liscic RM, Grinberg LT, Carter D, Paulsmeyer K, Taylor-Reinwald L, Gitcho M, Norton JB, Chakraverty S, Goate AM, Morris JC, Cairns NJ. Neuropathologic heterogeneity in HDDD1: a familial frontotemporal lobar degeneration with ubiquitin-positive inclusions and progranulin mutation. Alz Dis Assoc Disord 2007; 21: 1-7.

23. Bigio EH, Wu JY, Deng HX, Bit-Ivan EN, Mao QW, Ganti R, Peterson M, Saddique N, Geula C, Siddique T, Mesulam M. Inclusions in frontotemporal lobar degeneration with TDP-43 proteinopathy (FTLD-TDP) and amylotrophic lateral sclerosis (ALS) but not FTLD with FUS proteinopathy (FTLD-FUS), have properties of amyloid. Acta Neuropathol 2013; 125: 463-465.

24. Budini M, Romano V, Quadri Z, Buratti E, Baralle FE. TDP-43 loss of cellular function through aggregation requires additional structural determinants beyond its C-terminal Q/N prion-like domain. Hum Mol Genet 2015; 24: 9-20.

25. Cairns NJ, Grossman M, Arnold SE, Burn DJ, Jaros E, Perry RH, Duyckaerts C, Stankoff B, Pillon B, Skullerud K, Cruz-Sanchez FF, Bigio EH, Mackenzie IRA, Gearing M, Juncos JL, Glass JD, Yokoo H, Nakazato Y, Mosaheb S, Thorpe JR, Uryu K, Lee VM-Y, Trojanowski JQ. Clinical and neuropathologic variation in neuronal intermediate filament inclusion disease (NIFID). Neurology 2004; 63: 1376-1384.

26. Cairns NJ, Bigio EH, Mackenzie IRA, Neumann M, Lee VMY, Hatanpaa KJ, White CL, Schneider JA, Grinberg LT, Halliday G, Duyckaerts C, Lowe JS, Holm IE, Tolnay M, Okamoto K, Yokoo H, Murayama S, Woulfe J, Munoz DG, Dickson DW, Ince PG, Trojanowski JQ, Mann DMA. Neuropathologic diagnostic and nosological criteria for frontotemporal lobar degeneration: consen- 
sus of the Consortium for Frontotemporal Lobar Degeneration. Acta Neuropathol 2007; 114: 5-22.

27. Cleveland DW, Hwo SY, Kirschner MW. Purification of tau, a microtubule-associated protein that induces assembly of microtubules from purified tubulin. J Mol Biol 1977; 116: 207-225.

28. Cruts M, Gijselink I, van der ZJ, Engelborgs S, Wils H, Pirici $D$ Radamakers R, Vandenberghe R, Dermaut B, Martin JJ, van Duijn C, Peeters K, Sciot R, Santens P, De pooter T, Mattheijssens M, van den BM, Cuijt I, Vennekens K, De Deyn PP, Kumar-Singh S, Van Broeckhoven C. Null mutations in progranulin cause ubiquitin-positive frontotemporal dementia linked to chromosome 17q21. Nature 2006; 442: 920-924.

29. Davidson Y, Kelley T, Mackenzie IRA, Pickering Brown S, Du Plessis D, Neary D, Snowden JS, Mann DMA. Ubiquinated patholog ical lesions in frontotemporal lobar degeneration contain TAR DNA-binding protein, TDP-43. Acta Neuropathol 2007; 113: 521-533.

30. De Lacoste M, White CL. The role of cortical connectivity in Alzheimer's disease pathogenesis: a review and model system. Neurobiol Aging 1993; 14: 1-16.

31. Dormann D, Haass C. Fused in sarcoma (FUS): An oncogene goes awry in neurodegeneration. Mol Cell Neurosci 2013; 56: 475-486.

32. Goedert M, Clavaguera F, Tolnay M. The propagation of prion-like protein inclusions in neurodegenerative diseases. Trends Neurosci 2010; 33: 317-325.

33. Guerrero EN, Wang HB, Mitra J, Hegde PM, Stowell SE, Liachko NF, Kraemer BC, Garruto RM, Rao KS, Hegde ML. TDP-43/FUS in motor neuron disease: Complexity and challenges. Prog Neurobiol 2016; 145: 78-97.

34. Hardy J, Gwinn-Hardy K. Genetic classification of primary neurodegenerative disease. Science 1998; 282: 1075-1079.

35. Hauw JJ, Haik S, Duyckaerts C. Spreading of protein misfolding: A new paradigm in neurology. Rev Neurol 2015; 171: 825-831.

36. Hiorns RW, Neal JW, Pearson RCA, Powell TPS. Clustering of ipsilateral cortico-cortical projection neurons to area 7 in the rhesus monkey. Proc Roy Soc (Lond) 1991; 246: 1-9.

37. Hock EM, Polymenidou M. Prion-like propagation as a pathogenic principle in frontotemporal dementia. J Neurochem 2016; 138: 163-183.

38. Jeong YH, Ling JP, Lin SZ, Donde AN, Braustein KE, Majounie E, Traynor BJ, LeClair KD, Lloyd TE, Wong PC. TDP-43 cryptic exons are highly variable between cell types. Mol Neurodegener 2017; 12: 13

39. LaClair KD, Donde A, Ling JP, Jeong YH, Chhabra R, Martin LJ, Wong PC. Depletion of TDP-43 decreases fibril and plaque beta-amyloid and exacerbates neurodegeneration in an Alzheimer's mouse model. Acta Neuropathol 2016; 132: 859-873.

40. Luty AA, Kwok JBJ, Thompson EM, Blumsbergs P, Brooks WS, Loy CT, Dobson-Stone C, Panegyres PK, Hecker J, Nicholson GA, Halliday GM, Schofield PR. Pedigree with frontotemporal lobar degeneration-motor neuron disease and Tar DNA binding protein-43 positive neuropathology: genetic linkage to chromosome 9. BMC Neurology 2008; 8: 32.

41. Mackenzie IRA, Baker M, Pickering-Brown S, Hsinng GYR, Lindholm C, Dwosh E, Cannon A, Rademakers R, Hutton M, Feldman $\mathrm{HH}$. The neuropathology of frontotemporal lobar degeneration caused by mutations in the progranulin gene. Brain 2006; 129: 3081-3090.
42. Mackenzie IRA, Neumann M. Molecular neuropathology of frontotemporal dementia: insights into disease mechanisms from post-mortem studies. J Neurochem 2016; 138: 54-70.

43. Mukherjee O, Pastor P, Cairns NJ, Chakraverty S, Kauwe JSK, Shears S, Behrens MI, Budde J, Hinrichs AL, Norton J, Levitch D, Taylor-Reinwald L, Gitcho M, Tu PH, Grinberg LT, Liscic RM, Armendariz J, Morris JC, Goate AM. HDDD2 is a familial frontotemporal lobar degeneration with ubiquitin-positive tau-negative inclusions caused by a missense mutation in the signal peptide of progranulin. Ann Neurol 2006; 60: 314-322.

44. Onozato T, Nakahara A, Suzuki-Kouyama E, Hineno A, Yasude T, Nakamura T, Yahikozawa H, Watanabe M, Kayanuma K, Makishita H, Ohara S, Hashimoto T, Higuchi K, Sakai T, Asano K, Hashimoto T, Kanno H, Nakayama J, Oyangi K. Axonal TDP-43 in sporadic amylotrophic lateral sclerosis. Neuropathol Appl Neurobiol 2016; 42: 561-572.

45. Ratti A, Buratti E. Physiological functions and pathobiology of TDP-43 and FUS/TLS proteins. J Neurochem 2016; 138: 95-111.

46. Renton AE, Majounie E, Waite A, Simón-Sánchez J, Rollinson S, Gibbs JR, Schymick JC, Laaksovirta H, van Swieten JC, Myllykangas L, Kalimo H, Paetou A, Abramzon Y, Remes AM, Kaganovitch A, Scholz SW, Duckworth J, Ding J, Harmer DW, Hernandez DG, Johnson JO, Mok K, Ryten M, Trabzuni D, Guerreiro RJ, Orrell RW, Neal J, Murray A, Pearson J, Jansen IE, Sondervan D, Seelaar H, Blake D, Young K, Halliwell N, Callister JB, Toulson G, Richardson A, Gerhard A, Snowden J, Mann D, Neary D, Nalls MA, Peuralinna T, Jansson L, Isoviita VM, Kalvorinne AL, Hölttä-Vuori M, Ikonen E, Sulkava R, Benatar M, Wuu J, Chio A, Restagno G, Borghero G, Sabatelli M, The ITALSGEN Consortium, Heckerman D, Rogaeva E, Zinman L, Rothstein JD, Sendtner M, Drepper C, Eichler EE, Alkan C, Abdullaev Z, Pack SD, Dutra A, Pak E, Hardy J, Singleton A, Williams NM, Heutink P, Pickering-Brown S, Morris HR, Tienari PJ, Traynor BJ. A hexanucleotide repeat expansion in C9ORF72 is the cause of chromosome 9p21-linked ALS-FTD. Neuron 2011; 72: 257-268.

47. Steiner JA, Angot E, Brunden P. A deadly spread: cellular mechanisms of a-synuclein transfer. Cell Death Diff 2011; 18 : 1425-1433.

48. Suarez-Calvet M, Neumann M, Arzberger T, Abou-Ajram C, Funk E, Hartmann H, Edbauer D, Kremmer E, Gobl C, Resch M, Bourgeois B, Madl T, Reber S, Jutzi D, Ruepp MD, Mackenzie IRA, Ansorge O, Dormann D, Haass C. Monomethylated and unmethylated FUS exhibit increased binding to transportin and distinguish FTLD-FUS from ALS-FUS. Acta Neuropathol 2016; 131: 587-604.

49. Sun Yl, Chakrabarty A. Phase to phase with TDP-43. Biochemistry 2017; 56: 809-823.

50. Villoslada P, Melero I, Pablus JL, Martino G, Ucelli A, Montalban Y, Avila J, Rivest S, Acarin L, Appel S, Khoury SJ, McGeer P, Ferrer I, Delgado M, Obeso J, Schwartz M. Immunotherapy for neurological disease. Clin Immunol 2008; 128: 294-305.

51. Weingarten MD, Lockwood AH, Hwo SY, Kirschner MW. A protein factor essential for microtubule assembly. Proc Natl Acad Sci USA 1975; 72: 1858-1862.

52. Yaguchi M, Fujita Y, Amari M, Takatama M, Al-Sarraj S, Leigh PN, Okamoto K. Morphological differences of intraneural ubiquitin positive inclusions in the dentate gyrus and parahippocampal gyrus of motor neuron disease with dementia. Neuropathology 2004; 24: 296-301. 